\section{Questionnaire study of primary care physicians' referral patterns and perceptions of patients with epilepsy in a Brazilian city, 2005}

\author{
Vanessa Teixeira Müller ${ }^{1}$ \\ and Marleide da Mota Gomes ${ }^{1}$
}

The Brazilian health care system has undergone important changes, particularly in the development of the Unified Health System (Sistema Único de Saúde, or SUS in Portuguese) (1). Thirteen years since the SUS was implemented in Brazil, the federal Government has increased the use of norms and regulations aimed at rationalizing resources and prioritizing basic care within the System, not only by focusing on management at the state and municipal level, but also by making it a legal requirement that a minimum percentage of the municipal budget should be used for free health care (2). Likewise, new multidisciplinary family health-based systems such as the Family Health Program (Programa de Saúde da Família) and the Family Medical Program have been implemented in several Brazilian cities. The Family Health Program is based on the Cuban health care system (2). The Family Medical Program treats acute and chronic illnesses, including epilepsy, in addition to providing preventive care and health education to people of all ages and sexes.

Primary health care services are the backbone of the health care system, and the current shortage of neurologists reinforces the important role of family doctors and internists in the care of patients with epilepsy. Family doctors are the primary care providers for these patients, and the first physician to see a patient with epilepsy is usually a family doctor (3). But are they really prepared to care for these patients? And how much do they know about patients with epilepsy?

The aim of this paper was to evaluate, in a sample of family doctors, their referral patterns, perceptions and attitudes toward patients with epilepsy, general knowledge about epilepsy, knowledge of support services in the Brazilian primary care network for patients with epilepsy, and opinions on specific initiatives to improve care.

\section{METHODS}

Key words: epilepsy, primary health care, referral and consultation, Brazil.

\footnotetext{
Instituto de Neurologia Deolindo Couto, Universidade Federal do Rio de Janeiro, Programa de Epilepsia, Av. Venceslau Braz 95, Botafogo, Rio de Janeiro, RJ Rio de Janeiro 22290-140, Brasil. Send correspondence and reprint requests to: Vanessa Teixeira Müller, Instituto de Neurologia, Deolindo Couto, Universidade Federal do Rio de Janeiro, Programa de Epilepsia, Av. Venceslau Braz 95, Botafogo, Rio de Janeiro, RJ Rio de Janeiro 22290-140, Brasil; telephone: (21) 22976611.
}

This study was carried out in April 2005 in downtown Niterói, a city with a population of about 459000 inhabitants located in the state of Rio de Janeiro, Brazil. The quality of life in Niterói is considered one of the best among the 5600 Brazilian cities, according to the United Nation standards and the Instituto Brasileiro de Geografia e Estatistica (Brazilian Institute of Geography and Statistics) (4). 
The city has a well-organized and accessible Family Health Program based on the Cuban family medicine system (5). Of the 102 family doctors practicing in this city, 73 attended a three-hour conference on epilepsy. The questionnaires were handed to the doctors before the conference, and 71 questionnaires were returned by researchers before the conference. This response rate thus represented $70 \%$ of all family doctors in the city. The 63-item questionnaire (Appendix 1) was designed to examine demographics, training, practice, and referral patterns related to the care of patients with epilepsy. The questionnaire included items on family doctors' attitudes and perceptions of patients with epilepsy, referral patterns, knowledge of epilepsy, degree of satisfaction with the use of antiepileptic drugs, and opinions, experiences, and objectives for patients with epilepsy.

The questionnaires were included in the analysis if at least $75 \%$ of the items were answered, and all 71 questionnaires were eligible.

The responses for many items were standardized, e.g., attitudes and perceptions (agree or disagree), referral patterns (always, frequently, sometimes, or never), and satisfaction (satisfied or dissatisfied). Multiple choice responses (agree, disagree, or uncertain; always, frequently, sometimes, or never) were collapsed into two main groups to facilitate analysis (agree or disagree-uncertain, and always-frequently or sometimes-never).

The questionnaire was based on the instrument used in four similar studies (6-9). Confidentiality was assured by means of a coded number that was recorded for each doctor. All data were coded and analyzed with SPSS software (version 11.0).

\section{RESULTS}

Most of the physicians were women (71.8\%), and the majority had received undergraduate training at public universities (62.0\%). Approximately $70 \%$ of the respondents had been working in the Family Medical Program for at least five years, but only a minority $(19.4 \%)$ were specialized in family medicine. Each physician provided care for 250 to 450 families, and $71.0 \%$ of them saw more than two patients with epilepsy per year.

Most of the family doctors believed that patients with epilepsy can attain a good quality of life $(98.6 \%)$, even though some of the doctors were prone to believe in the existence of an epileptic personality $(21.1 \%)$. They believed that knowledge about these patients in the general population is poor, and people are generally afraid of them, and that employers tend to discriminate against them $(80.0 \%)$. According to the family doctors, patients with epilepsy should declare their disorder on applying for a job (42.3\%) and for a driver's license $(52.9 \%)$. Most participants considered their undergraduate medical training in epilepsy to be unsatisfactory $(69.0 \%)$. They also believed that a neurologist should be responsible for diagnostic procedures and initial antiepileptic drug prescribing, and that the family doctor should only be responsible for subsequent care $(69.0 \%)$. Even though they underestimated their knowledge, most participants answered items on specific knowledge of epilepsy correctly.

Some items focused on the family doctors' opinions about specific initiatives to improve care. Clinical guidelines and continuing medical education seminars were seen as very helpful by nearly all participants $(90.1 \%$ and $100.0 \%$, respectively). Better access to clinical laboratory tests was also seen as very important. A dichotomy was noted when they were asked whether assistance by nurses specialized in epilepsy would improve care: $47 \%$ of them agreed, whereas $53 \%$ disagreed. Most respondents $(93.0 \%)$ always or frequently referred their patients with epilepsy to the neurologist. Although $39.4 \%$ would regularly initiate antiepileptic drug therapy without referring the patient to a specialist, most family doctors never do so. Most family doctors would always or usually order tests to measure serum antiepileptic drug levels (52.4\%) before changing treatment, and would never modify the treatment proposed by a neurologist (Table 1). Family doctors indicated that they and their peers either were not fully satisfied or were dissatisfied with their knowledge of epilepsy, and that they were unfamiliar with antiepileptic drugs, their side effects, and specific uses (Table 2).

The medical school was the setting where most family doctors had first observed and treated patients with epilepsy, and where they acquired further knowledge of the disorder. According to our respondents, the most qualified health care professionals for the follow-up of patients with epilepsy were neurologists $(58.9 \%)$, followed by family doctors $(35.7 \%)$. The main goals for patients with epilepsy were ranked as preventing seizures $(42.0 \%)$, reducing the impact on everyday life $(32.0 \%)$, maintaining normal activities $(22.0 \%)$, and patient education $(4.0 \%)$. Family doctors highlighted the importance of patients' knowledge about their condition $(35.6 \%)$ and the limitations in everyday life $(32.2 \%)$ (Table 3$)$.

When we stratified our sample of respondents by age, sex, years of experience as a doctor, 
Temas de actualidad $\bullet$ Current topics

TABLE 1. Patterns of referral and practice with epilepsy patients as reported by Brazilian family doctors in a questionnaire study, 2005

\begin{tabular}{lrrrr}
\hline & \multicolumn{2}{c}{ Always/Frequently } & & \multicolumn{2}{c}{ Occasionally/Never } \\
\cline { 2 - 3 } & No. & $\%$ & No. & \% \\
\hline I refer epilepsy patients to a neurologist & 66 & 93.0 & 5 & 7.0 \\
I start treatment for patients with epilepsy & 28 & 39.4 & 43 & 60.6 \\
I modify the treatment proposed by the neurologist & 0 & 0 & 71 & 100.0 \\
$\begin{array}{l}\text { Would you determine serum antiepileptic drug levels if } \\
\quad \text { you were to modify an antiepileptic drug treatment?a }\end{array}$ & 33 & 52.4 & 30 & 47.6 \\
\hline
\end{tabular}

a For some items studied, the total number of responses was less than 71 because questionnaires were included in the analysis when at least $75 \%$ of the items were answered.

TABLE 2. Family doctors' personal satisfaction rate with care of epilepsy patients, as reported in a questionnaire study in Brazil, 2005

\begin{tabular}{lrrrr}
\hline & \multicolumn{2}{c}{ Satisfied } & & \multicolumn{2}{c}{ Dissatisfied } \\
\cline { 2 - 3 } \cline { 5 - 5 } & No. & No. & & \\
\hline With multiple antiepileptic drugs and their specific uses & 21 & 30.4 & & 48 \\
With the side effects of antiepileptic drugs & 4 & 5.8 & 65 & 69.6 \\
With their knowledge of epilepsy & 5 & 7.1 & 65 & 94.2 \\
With guidelines given in medical training & 12 & 17.4 & 57 & 92.9 \\
\hline
\end{tabular}

a The total number of responses was less than 71 because questionnaires were included in the analysis when at least $75 \%$ of the items were answered.

personal satisfaction with their knowledge about epilepsy, and referral patterns, none of the comparisons between subgroups in our study sample yielded statistically significant differences.

\section{DISCUSSION}

Despite efforts by the Brazilian Government to improve the Family Health Program and the Family Medical Program, there is a scarcity of primary care studies in Brazil, especially on primary care physicians' perceptions and referral patterns for patients with epilepsy. Previous work showed, however, that general practitioners considered quality of life and education for patients with epilepsy as crucial factors in the treatment of this disorder $(3,9)$.

It is important to recognize that epilepsy, like any chronic or disabling condition, can adversely affect a person's self-image, self-esteem, and interactions with family, friends, and society in general (3). However, most family doctors in our study tended to disregard the possible adverse effects of epilepsy on emotional well-being, health status, rights, and functional potential in comparison to the general population. Most of them agreed that patients with epilepsy can attain a good quality of life, even though some were prone to believe in the existence of an epileptic personality.

Medical students' training in neurology and the pharmacological aspects of epilepsy is important, but their training in the psychosocial aspects of epilepsy seemed to be less than optimal, according to the present study. The traditional medical and pharmacological approach to the treatment of epilepsy and seizures overlooks the psychosocial issues faced by patients. It is in this psychosocial dimension-in which patients experience the greatest difficulties-where doctors have received the least training (10). A number of doctors recognize that there is prejudice in the general population and among employers regarding patients with epilepsy, as they believe that these patients are more likely to have emotional and relationship problems (6). In the present study, the family doctors' attitudes and perceptions of health care were less stereotyped and negative than in at least one earlier study (3). Our findings are consistent with other studies $(6,9)$ that denied that epilepsy patients contribute less to society than people without this disorder, or that they are less able than others to establish close relationships. According to a survey of doctors in the Canary Islands (Spain) (9), patients with epilepsy can lead normal lives, but should avoid stressful 
TABLE 3. Summary of responses by family doctors in Brazil to a questionnaire on referral patterns and treatment of patients with epilepsy, 2005

\begin{tabular}{|c|c|c|}
\hline Variable & No. & $\%$ \\
\hline \multicolumn{3}{|l|}{ Main source of knowledge } \\
\hline University & 25 & 48.1 \\
\hline Postgraduate training or residency & 9 & 17.3 \\
\hline Primary care & 9 & 17.3 \\
\hline Other health units & 2 & 2.8 \\
\hline Elsewhere & 7 & 13.5 \\
\hline \multicolumn{3}{|l|}{ Family doctor's first contact with seizures } \\
\hline University & 17 & 27.0 \\
\hline Postgraduate training or residency & 4 & 6.3 \\
\hline Primary care & 1 & 1.6 \\
\hline Other health units & 10 & 15.9 \\
\hline Elsewhere & 31 & 49.2 \\
\hline \multicolumn{3}{|l|}{ First patient with epilepsy treated } \\
\hline University & 19 & 29.2 \\
\hline Postgraduate training or residency & 9 & 13.8 \\
\hline Primary care & 10 & 15.4 \\
\hline Other health units & 14 & 21.5 \\
\hline Elsewhere & 9 & 13.8 \\
\hline No experience & 4 & 6.2 \\
\hline \multicolumn{3}{|l|}{$\begin{array}{l}\text { The health care professional best qualified to } \\
\text { treat epilepsy }\end{array}$} \\
\hline Family doctor & 20 & 35.7 \\
\hline Pediatric neurologist & 2 & 3.6 \\
\hline Neurologist & 33 & 58.9 \\
\hline Other & 1 & 1.8 \\
\hline \multicolumn{3}{|l|}{ Main goals of epilepsy treatment } \\
\hline Preventing seizures & 21 & 42.0 \\
\hline Reducing the impact on daily life & 16 & 32.0 \\
\hline Maintaining the patient's normal activities & 11 & 22.0 \\
\hline Patient education & 2 & 4.0 \\
\hline \multicolumn{3}{|l|}{ Main goals of patient education } \\
\hline Compliance with treatment or follow-up & 7 & 11.9 \\
\hline $\begin{array}{l}\text { Information about treatment and its side } \\
\text { effects }\end{array}$ & 11 & 18.6 \\
\hline Information about the patient's condition & 21 & 35.6 \\
\hline Limitations of epilepsy in everyday life & 19 & 32.2 \\
\hline Information on working or driving & 1 & 1.7 \\
\hline
\end{tabular}

a The total number of responses is less than 71 because questionnaires were included in the analysis when at least $75 \%$ of the items were answered.

physical and mental work. With regard to employability, the results from our sample are more conservative than those from previous studies $(3,9)$.

Our research showed that family doctors, like general practitioners in other studies $(9,11-14)$, rely on referrals to specialists to initiate treatment, regardless of experience, specialty or knowledge of epilepsy (as shown by the appropriate answers in items about the disorder itself). About one-third $(35.7 \%)$ of the participating family doctors considered themselves the most important health care professionals in the care of patients with epilepsy.
This rate is lower than that reported in an earlier study, which focused on general practitioners' attitudes towards epilepsy and treatment (8). It is noteworthy that only $7.1 \%$ of the family doctors in our survey were confident about their knowledge of epilepsy, only $30.4 \%$ felt confident about their ability to manage multiple antiepileptic drug treatment (with regard to specific indications for each drug), and only $5.8 \%$ felt confident about their knowledge of side effects. These results are similar to those in other studies (3, 6-9), and are considerable barriers to effective health care. In our study, as in others (6, 7 ), most family doctors felt uncomfortable with epilepsy patients, and these doctors also believed that their peers were not completely satisfied or were dissatisfied with their knowledge of epilepsy.

The role of family doctors in the care of patients with epilepsy is indispensable due to the scarcity of specialized centers and the insufficient number of neurologists in Brazil to care for all patients. In the course of their activities, family doctors should understand all antiepileptic drug options, and clearly communicate with their patients to ensure treatment compliance (13). Unfortunately, our participants showed evidence of inadequate knowledge of epilepsy, or-because they underestimating their knowledge-failed to fulfill their role.

Nurses specialized in epilepsy might improve outcomes for patients, although there is no clear evidence of their effectiveness in care improvement $(8,15)$. Our study found that almost $50 \%$ of the family doctors agreed that the use of community nurses could improve treatment for patient with epilepsy.

As in other studies $(8,11)$, nearly all the family doctors felt that specific guidelines would be helpful in improving their clinical skills in patient care.

We should note a few limitations of this study. First, the findings may be biased since some of the questions might have been answered in a "politically correct" manner that did not reflect the doctors' actual opinion. Second, the sample was representative of the doctors working in Niterói, but does not necessarily represent all physicians in the Brazilian Family Health Program. This limits the generalizability of the results. However, our questionnaire was one of the largest and most elaborate ever used in Brazil on this subject.

We conclude that continuing education for family doctors, especially in current treatment trends and patient education strategies, could improve physicians' attitude towards epilepsy, and may help to improve family doctors' perceptions of the disorder. Doctors and other professionals should also be sensitive to patients' specific needs, and should be aware of their satisfaction with treatment. An effective and efficient program for patients with epilepsy is necessary to ensure adequate 
education for all parties involved in this type of care, and to improve referral patterns. We infer that the Family Medical Program in a city such as Niterói has the means to cope with epilepsy care at the primary level, because of the human resources available and professionals' interest in improving their qualifications. However, there remain other issues concerning secondary and tertiary care that will need to be resolved in order to further improve health care and referral patterns.

\section{SINOPSIS}

\section{Encuesta sobre los patrones de remisión y las percepciones de los médicos de atención primaria con respecto a los pacientes con epilepsia en una ciudad brasileña, 2005}

A una muestra de médicos de familia del Programa de Médicos de Familia de Niterói, Río de Janeiro, Brasil, se aplicó en abril de 2005 un cuestionario autoadministrado para de- terminar la percepción de los médicos de atención primaria sobre la calidad del servicio para epilepsia y los patrones de remisión y su opinión sobre la atención que se brinda. Los encuestados consideraron que los neurólogos deben ser los responsables del diagnóstico y de la prescripción inicial de medicamentos antiepilépticos, mientras que los médicos de familia se deben responsabilizar de la atención subsiguiente. Los encuestados informaron estar insatisfechos con sus conocimientos sobre la epilepsia y los medicamentos antiepilépticos. Se consideró que los profesionales mejor calificados para la atención de la epilepsia son los neurólogos (58,9\%), seguidos de los médicos de familia $(35,7 \%)$. Casi todos los encuestados consideraron que los lineamientos y seminarios mejoraron su capacidad para atender a sus pacientes. Los encuestados no se sentían seguros de la atención que brindaban a los pacientes con epilepsia y por lo general los remitían al neurólogo. Sin embargo, el Programa de Médicos de Familia tiene un potencial inexplotado para tratar a los pacientes con epilepsia, debido al interés de estos profesionales en mejorar su calificación.

Palabras clave: epilepsia, atención primaria de salud, remisión y consulta, Brasil.

\section{REFERENCES}

1. Collins C, Araujo J, Barbosa J. Decentralising the health sector: issues in Brazil. Health Policy. 2000; 52(2): 113-27.

2. Marques RM, Mendes A. A política de incentivos do Ministério de Saúde para a atenção básica: uma ameaça à autonomia dos gestores municipais e ao principio da integralidade? Cad Saúde Pública. 2002; 18(suppl): 163-71.

3. Frith JF, Harris MF, Beran RG. Management and attitudes of epilepsy by a group of Sydney practitioners. Epilepsia. 1994; 35: 1244-7.

4. Brasil. Ministério do Planejamento, Orçamento y Gestão. Censo, Instituto Brasileiro de Geografia e Estadistica 2000. Cidades. Available from: http:// www.ibge.gov.br Accessed 31 May 2007.

5. Teixeira SCS, Monteiro VO, Miranda VA. Programa Médico de Família Município de Niterói. Estudos Avançados. 1999; 13: 147-55.
6. Gomes MM. Doctors' perspectives and practices regarding epilepsy. Arq Neuropsiquiatria. 2000; 58(2-A): 221-6.

7. Moore JL, McAuley JW, Mott D, Reeves AL, Bussa B. Referral characteristics of primary care phisicians for seizure patients. Epilepsia. 2000; 41(6): 744-8.

8. Thapar AK, Stott NCH, Richens A, Kerr M. Attittudes of the GPs to the care of people with epilepsy. Family Practice. 1998; 15: 437-42.

9. Pérez-Pérez J, Sosa AM, GonzálezCasanova S. Conocimientos, control clínico y actitudes de los médicos de Atención Primaria frente a los pacientes epilépticos. Resultados previos. Rev Neurol. 2005; 40(7): 385-93.

10. Devinsky O, Penry JK. Quality of life in epilepsy: the clinician's view. Epilepsia. 1993; 34(Suppl 4): S4-S7.

11. Li L, Fernandes P, Mory S, Noronha A, Boer H, Espindola J, et al. Manejo da epilepsia na rede básica de saúde no Brasil: os profissionais estão preparados? Rev Panam Salud Publica. 2005; 18 : 296-302.

12. Bradley P, Lindsay B. Epilepsy clinics versus general neurology or medical clinics (Cochrane Review). In: The Cochrane Library, Issue 4, 2002. Oxford: Update Software.

13. Montouris GD. How will primary care physicians, specialists, and managed care treat epilepsy in the new millennium? Neurology. 2000; 55(11 Suppl 3): S42-S4.

14. Sawhney IM, Lekra OP, Shashi JS, Prabhakar S, Chopra JS. Evaluation of epilepsy management in a developing country: a prospective study of 407 patients. Acta Neurol Scand. 1996; 94(1): 19-23.

15. Bradley P, Lindsay B. Specialist epilepsy nurses for treating epilepsy (Cochrane Review). In: The Cochrane Library, Issue 1, 2001. Oxford: Update Software. 
APPENDIX 1. English translation of questionnaire used to study primary care physician's referral patterns and perception of patients with epilepsy in Brazil, 2005

\begin{tabular}{|l|l|}
\hline A. Please provide the following information in the right-hand column: & \multicolumn{1}{|c|}{ code: . . . . . } \\
\hline Name: & \\
\hline 1. Age & \\
\hline 2. Sex & \\
\hline 3. Specialty & \\
\hline 4. Year of graduation & \\
\hline 5. Undergraduate medical training (medical school) & \\
\hline 6. Number of epilepsy patients seen per year & \\
\hline 7. Number of families under your care in the Family Medical Program & \\
\hline 8. Years of experience as a family doctor & \\
\hline
\end{tabular}

\section{B. Please answer the following questions. Mark only one choice with an $\mathrm{X}$.}

\begin{tabular}{|c|c|c|c|}
\hline & Agree & Disagree & Uncertain \\
\hline \multicolumn{4}{|l|}{ 1. Patients with epilepsy can have a high quality of life } \\
\hline \multicolumn{4}{|l|}{ 2. Patients with epilepsy are less able than others to establish close relationships } \\
\hline \multicolumn{4}{|l|}{ 3. There is an epileptic personality } \\
\hline \multicolumn{4}{|l|}{ 4. A lot of people do not understand patients with epilepsy } \\
\hline \multicolumn{4}{|l|}{ 5. A lot of people are afraid of patients with epilepsy } \\
\hline \multicolumn{4}{|l|}{ 6. Although they deny it, a lot of employers discriminate against patients with epilepsy } \\
\hline \multicolumn{4}{|l|}{ 7. Patients with epilepsy should avoid strenuous physical work } \\
\hline \multicolumn{4}{|l|}{ 8. Patients with epilepsy should avoid stressful mental work } \\
\hline \multicolumn{4}{|l|}{ 9. Behavioral disturbances are more frequent in patients with epilepsy than in others } \\
\hline \multicolumn{4}{|l|}{ 10. Changes in mood are more frequent in patients with epilepsy than in others } \\
\hline \multicolumn{4}{|l|}{ 11. Emotional imbalance is more frequent in patients with epilepsy than in others } \\
\hline \multicolumn{4}{|l|}{ 12. Patients with epilepsy are more aggressive than others } \\
\hline \multicolumn{4}{|l|}{ 13. Patients with epilepsy are less intelligent than others } \\
\hline \multicolumn{4}{|l|}{ 14. Patients with epilepsy are less able to concentrate than others } \\
\hline \multicolumn{4}{|l|}{ 15. Patients with epilepsy are less active than others } \\
\hline \multicolumn{4}{|l|}{ 16. Patients with epilepsy are more irritable than others } \\
\hline \multicolumn{4}{|l|}{ 17. Poor attendance at school or work is more frequent among patients with epilepsy } \\
\hline \multicolumn{4}{|l|}{ 18. Patients with epilepsy are less productive at work than others } \\
\hline \multicolumn{4}{|l|}{ 19. Patients with epilepsy have more learning difficulties than others } \\
\hline 20. Injuries and accidents at work are more frequent among patients with epilepsy & & & \\
\hline
\end{tabular}




\begin{tabular}{|c|c|c|c|c|}
\hline & Always & Frequently & Occasionally & Never \\
\hline \multicolumn{5}{|c|}{ 21. Patients with epilepsy contribute less to society than others } \\
\hline \multicolumn{5}{|l|}{ 22. Patients with epilepsy should not get married } \\
\hline \multicolumn{5}{|c|}{ 23. Patients with epilepsy do not have normal family relations } \\
\hline \multicolumn{5}{|c|}{ 24. Families in which a member has epilepsy suffer more } \\
\hline \multicolumn{5}{|c|}{ 25. Patients with epilepsy are treated as a minority group } \\
\hline \multicolumn{5}{|c|}{ 26. Patients with epilepsy must declare their disorder when applying for a job } \\
\hline \multicolumn{5}{|c|}{ 27. Patients with epilepsy must declare their disorder when applying for a driver's license } \\
\hline \multicolumn{5}{|c|}{ 28. A lot of doctors are unfamiliar with antiepileptic drugs and their specific use } \\
\hline \multicolumn{5}{|c|}{ 29. Monotherapy is more appropriate for patients with epilepsy } \\
\hline \multicolumn{5}{|c|}{ 30. A lot of doctors are unfamiliar with the side effects of antiepileptic drugs } \\
\hline \multicolumn{5}{|l|}{ 31. A single seizure can be typified as epilepsy } \\
\hline \multicolumn{5}{|c|}{ 32. Epilepsy may be considered primary (hereditary) or secondary } \\
\hline \multicolumn{5}{|c|}{ 33. Multiple seizures caused by hypoglycemia can be typified as epilepsy } \\
\hline \multicolumn{5}{|c|}{ 34. Many doctors are knowledgeable about patients with epilepsy } \\
\hline \multicolumn{5}{|l|}{ 35. Medical training in epilepsy is unsatisfactory } \\
\hline \multicolumn{5}{|c|}{$\begin{array}{l}\text { 36. Neurologist should take responsibility for diagnostic procedures and antiepileptic } \\
\text { drug prescriptions, while family doctors should be in charge of subsequent care }\end{array}$} \\
\hline \multicolumn{5}{|c|}{$\begin{array}{l}\text { Do you believe any of the interventions below could improve treatment for patient } \\
\text { with epilepsy? }\end{array}$} \\
\hline \multicolumn{5}{|c|}{ 37. Clinical guidelines for family doctors on the treatment of epilepsy } \\
\hline \multicolumn{5}{|l|}{ 38. Recycle and update courses on epilepsy } \\
\hline \multicolumn{5}{|l|}{ 39. Use of community nurses specialized in epilepsy } \\
\hline \multicolumn{5}{|l|}{ 40. Better access to complementary tests } \\
\hline \multicolumn{5}{|c|}{ C. Please answer the following questions. Mark only one choice with an X. } \\
\hline \multicolumn{5}{|l|}{ 1. I refer patients with epilepsy to a neurologist } \\
\hline \multicolumn{5}{|l|}{ 2. I start treatment of patients with epilepsy } \\
\hline \multicolumn{5}{|l|}{ 3. I modify the treatment proposed by the neurologist } \\
\hline \multicolumn{5}{|c|}{$\begin{array}{l}\text { 4. Would you determine serum concentrations of antiepileptic drugs } \\
\text { if you were to modify an antiepileptic drugs treatment? }\end{array}$} \\
\hline \multicolumn{5}{|c|}{ D. Please answer the following questions. Mark only one choice with an $\mathrm{X}$. } \\
\hline Family doctor's personal satisfaction rate & \multicolumn{2}{|c|}{ Satisfied } & \multicolumn{2}{|c|}{ Dissatisfied } \\
\hline \multicolumn{5}{|c|}{ 1. With their knowledge of antiepileptic drugs and their specific use } \\
\hline 2. With the side effects of antiepileptic drugs & & & & \\
\hline 3. With their knowledge of epilepsy & & & & \\
\hline 4. Satisfactory guidelines given in medical training & & & & \\
\hline
\end{tabular}




\section{Please select only one option with an $\mathrm{X}$.}

Where did you acquire your main source of knowledge of epilepsy?
a. University
b. Postgraduate training or residency
c. Primary care
d. Other health units
e. Elsewhere

Where did you see your first patient with an epileptic seizure?
a. University
b. Postgraduate training or residency
c. Primary care
d. Other health units
e. Elsewhere

Where did you treat your first patient with epilepsy?
a. University
b. Postgraduate training or residency
c. Primary care
d. Other health units
e. Elsewhere
f. No experience

Who is best qualified to treat patients with epilepsy?
a. Family doctor
b. Pediatric neurologist
c. Neurologist
d. Other

What is the main outcome to achieve in patients with epilepsy?
a. Prevent seizures
b. Reduce impact on daily life
c. Ensure the patient remains employed
d. Educate patients

What is the main outcome to achieve for patient education?
a. Compliance with treatment and follow-up
b. Knowledge of treatment and its side effects
c. Knowledge of the patient's condition
d. Limitations of epilepsy in practical life
e. Information on work and driving 